\title{
Haptolana pholeta, sp. nov., The First Subterranean Flabelliferan Isopod Crustacean (Cirolanidae) from Australia
}

\author{
Niel L. Bruce ${ }^{\mathrm{A}}$ and W. F. Humphreys ${ }^{\mathrm{B}}$ \\ A Queensland Museum, P.O. Box 3300, South Brisbane, Qld 4101, Australia. \\ Present address: Zoologisk Museum, University of Copenhagen, \\ Universitetsparken 15, DK 2100, Copenhagen $\varnothing$, Denmark. \\ B Western Australian Museum, Francis Street, Perth, W.A. 6000, Australia.
}

\begin{abstract}
The genus Haptolana Bowman, 1966 is rediagnosed, and is characterised by the unique synapomorphy of pereopods 2-7 having an expanded propodus, the palm of which contains a V-shaped series of spines and a haptorial dactylus which folds in between these spines. Haptolana pholeta, from anchialine waters on Barrow Island, Western Australia, is described, and is distinguished from the two other species of Haptolana in possessing a frontal lamina that is anteriorly rounded, that separates the antennule bases and is visible in dorsal view.
\end{abstract}

\section{Introduction}

That Australia is an arid continent can be regarded as a truism, and the freshwater fauna of the continent is inevitably found to be impoverished when compared with the wetter continents. Cave waters in Australia are correspondingly scarce and have, until the present decade, received little attention from biologists. Recently, several new cave-dwelling crustanceans have been described from Australia, all from tropical western and northern Australia (Holthuis 1986; Bruce 1992; Poore and Humphreys 1992; Wilson and Ponder 1992), indicating that a reasonably rich subterranean aquatic fauna does exist. The discovery of a blind subterranean cirolanid isopod is here added to those recent discoveries; it is both the first cirolanid and the first flabelliferan isopod recorded from subterranean waters in Australia (the ordinal status of Wilson and Ponder's taxon is at present unresolved).

Cave-dwelling isopods have been reviewed by Botosaneanu (1986) and Bănărescu (1990). Cirolanids are arguably the best represented of the subterranean isopod families, with 17 genera and nearly 50 species (Botosaneanu et al. 1986, updated here by N.L.B.). Most of these records are from two regions: the Western North Atlantic, comprising the Caribbean and adjacent continental regions of Mexico and the United States of America, and the Mediterranean continental and island regions of Europe, the Middle East and North Africa. Scattered records of Anopsilana Paulian \& Delamare Deboutteville exist from elsewhere (Paulian and Delamare Deboutteville 1956; Bowman and Iliffe 1987; Bruce and Iliffe 1993), but only the north-eastern corner of Africa (Ethiopia and Somalia) has more than a single record (Messana 1990) of stygial cirolanid isopods. There is only one record of a subterranean cirolanid (Anopsilana poissoni Paulian \& Delamare Deboutteville from Madagascar) from the Southern Hemisphere. The discovery of a species of Haptolana from Western Australia is therefore of some interest. 


\section{Methods}

All appendages were dissected from the right-hand side with the exception of the mandibles, both of which were dissected.

Specimens are deposited at the Western Australian Museum, Perth (WAM), and Queensland Museum, Brisbane (QM)

\section{Terminology}

The word prehensile has been used to describe the dactylus of isopods that have hook-like or claw-like pereopods. Kensley and Schotte (1989) define the term simply as 'adapted for holding or clinging', and define ambulatory as 'adapted to walking'. Notably, the word prehensile is used to describe the dactylus of cymothoid isopods and is one of the defining characters of that family. Notenboom (1984) discussed the use of the term, misquoting a personal communication from $\mathbf{N}$. $\mathbf{L}$. Bruce in this regard. The opportunity is taken here to present a reassessment of the terms used in describing the pereopods of cirolanids and related flabelliferan families.

Those isopods with a markedly swollen propodus (usually pereopod 1) and a long dactylus have been described as having a subchelate first pereopod (e.g. Serolidae-see Harrison and Poore 1984; Anthuridea - see Poore and Lew Ton 1988). In the Cirolanidae there are a few genera in which the dactylus is elongate (0.5-1.0 times as long as the propodus) and may or may not be reflexed against the propodus. Such a dactylus has been referred to as prehensile or subprehensile. It is clear that such a dactylus is not prehensile in the sense of those of the Cymothoidae, where the dactylus is stout, strongly curved or claw-like and usually extends to the merus.

The dactylus of genera such as Haptolana are better described as haptorial (clasping), and those in which the dactylus is short (less than 0.5 times the length of the propodus) and not obviously reflexed can be distinguished as ambulatory (e.g. Cirolana, Anopsilana) or subhaptorial (Metacirolana). Examples of genera with haptorial dactyli are Haptolana (pereopods 2-7), Arubolana Botosaneanu \& Stock, 1979, Hansenolana Stebbing, 1990 (see Bruce 1986), and Speocirolana Bolivar (pereopods 1 or 1-3) (see Bowman 1982). Bahalana Carpenter, 1981 has pereopods 1-3 with elongate dactyli (about 0.86 times as long as propodus), but these are neither strongly curved nor reflexed and therefore cannot be considered prehensile or haptorial. They are simply long (see Notenboom 1981; Bowman 1987). It should also be borne in mind that intermediate forms of the dactylus may occur.

The abbreviation PMS is used for plumose marginal setae.

\section{Taxonomy}

\section{Family Cirolanidae Dana \\ Genus HAPTOLANA Bowman}

Haptolana Bowman, 1966: 105.-Messana and Chelazzi, 1984: 296; Bruce, 1986: 222; Kensley and Schotte, 1989: 137.

Type species: Haptolana trichostoma Bowman, 1966, by monotypy.

\section{Diagnosis}

Body smooth, unornamented; without chromatophores or pigment; eyes absent. Pleon with 5 unfused segments; posterolateral margins of pleonite 4 extending posteriorly beyond pleonites 3 and 5; pleotelson not fused to pleonite 5. Ventral surface of frontal lamina flat. Pereopod articles not flattened or expanded, with few setae. Pereopod 1 ambulatory, pereopods 2-7 with moderately expanded propodus, $2 \cdot 0-3 \cdot 0 \times$ as long as greatest width, posterior margin convex, palm provided with large (10-26\% propodal length) spines in 2 divergent rows (forming a V-shape); dactylus of pereopods 2-7 haptorial, $0 \cdot 6-1 \cdot 0 \times$ length of propodus, folding between palm spines. Pleopods 3-5 endopods without PMS, smaller than exopod. Uropod with peduncle mesial margin produced.

\section{Additional Characters}

Articles 1 and 2 of antennule peduncle fused ( $H$. trichostoma, $H$. pholeta, sp. nov.); antenna peduncle with 5 articles. Mandible incisor, spine row, molar process and palp entire; maxillule entire; maxilla entire. Maxilliped entire, endite with 1 coupling hook. Penial papillae small, close set in medial position at posterior of sternite 7 (not described for $H$. trichostoma). Both rami of pleopods 1 and 2 with PMS; pleopod 1 peduncle shorter 
$(0 \cdot 5-0 \cdot 8)$ than wide, rami not operculate; appendix masculina of pleopod 2 arising basally; exopods of pleopods 3-5 with entire or partial suture. Uropods and posterior margin of pleotelson with PMS, amongst which are set 2-17 stout spines.

\section{Remarks}

The principal and diagnostic synapomorphy for Haptolana is the haptorial morphology of pereopods 2-7. While it is possible that this is a convergent character, the uniformity of the shape and spinal armature of the propodus suggest otherwise. The propodus and dactylus of pereopods $4-7$, in particular, differ substantially from those of most other cirolanid genera, which are usually straight-sided, slender, with short spines on the posterior margin, and have a short dactylus $(0.3$ times the length of propodus in Cirolana species, 0.3-0.5 times the length of propodus in Natatolana species: Bruce 1986). The endopods of pleopods 3-5 are without plumose marginal setae, but this loss is associated with freshwater habitats (Bruce 1981, 1986; Bowman and Franz 1982) and is not here considered to be of phylogenetic significance. The antennule, antennal, mouthpart, pleopod, uropod and telson morphology is otherwise similar to that of Cirolana Leach and, within that genus, most similar to the Cirolana parva group of species.

The only significant differences that exist between species of Haptolana are in the shape of the frontal lamina, the appendix masculina, and possibly details of the ischium, merus and carpus of pereopods 4-7. In Haptolana pholeta, sp. nov. the frontal lamina is flat, broadly rounded anteriorly, and visible in dorsal view; in ventral view it clearly separates the antennule bases. In the other two species the frontal lamina is pentagonal, and does not extend anteriorly between the antennule bases. The appendix masculina of all species arise basally, but that of $H$. pholeta is straight, while those of the other two species arc strongly in a lateral direction. Finally, pereopods 4 and 5 of $\mathrm{H}$. trichostoma, as figured by Bowman (1966), appear to have the ischium, carpus and merus somewhat flattened, and with a continuous row of setae along their posterior margins (Bowman did not illustrate pereopods 6 or 7); the pereopods otherwise are similar to those of $H$. somala and $H$. pholeta.

Although the difference in morphology of the frontal lamina is substantial, that and the other differences mentioned are well within the limits of accepted generic boundaries.

Contrary to the doubts expressed by Messana and Chelazzi (1984) and Messana (1990) we would uphold the placement of $H$. somala in Haptolana.

\section{Included Species}

Haptolana trichostoma Bowman, 1966. Known only from the type locality, a freshwater cave in Cuba.

Haptolana somala Messana \& Chelazzi, 1984. Known from springs and wells in several localities in eastern Somalia, up to $150 \mathrm{~km}$ from the coast.

Haptolana pholeta, sp. nov. Described here from Western Australia.

\section{Distribution}

The three species of Haptolana are all from tropical regions (see Fig. 4) that would have been under sea water prior to the sea-level changes of the Miocene, and therefore correspond to the concept of Tethys relicts given by Newman (1991).

\section{Key to the Genus Haptolana}

1. Pleotelson subtruncate, posterior margin with 17 spines; distal margin of uropod endopod subtruncate H. trichostome

Pleotelson linguiform, posterior margin with 10 or fewer spines; uropod endopod with mesial and lateral margins converging to narrow apex

2. Posterior margin of pleotelson with 2 spines; frontal lamina pentagonal, anterior margin acute,

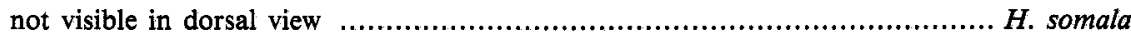

Posterior margin of pleotelson with 8-10 spines; frontal lamina widest anteriorly, anterior margin rounded, visible in dorsal view 
Haptolana pholeta, sp. nov.

(Figs 1-3)

\section{Material Examined}

All material is from Barrow I., W.A., coll. W. F. Humphreys and B. Vine.

Holotype. $\sigma(6.5 \mathrm{~mm})$, Cave B1, 20 $0^{\circ} 48^{\prime} \mathrm{S} ., 115^{\circ} 19^{\prime} \mathrm{E}$., 29.vii.1992, in traps (WAM 41/93).

Paratypes. $20^{*}(4 \cdot 5,4.8 \mathrm{~mm})$, ᄋ (non-ovig., $4.6 \mathrm{~mm}$ ), same data as holotype (WAM 42/93); 2o (non-ovig., $5 \cdot 1,6.6 \mathrm{~mm}$ ), Cave B1, 25.vii.1992 (WAM 43/93); manca, Cave B1, 27.iv.1992 (WAM 45/93); ơ (4.8 mm), 2 (non-ovig., 5.8, 6.3 mm), Well B2, 2043'S.,115²1'E., 25.vii.1992 (QM W18460); O' $(6 \cdot 3 \mathrm{~mm})$, Well L16, 20 $0^{\circ} 49^{\prime} \mathrm{S} ., 115^{\circ} 23^{\prime} \mathrm{E} ., 27 . v i i .1992$, dead on collection (WAM W44/93).

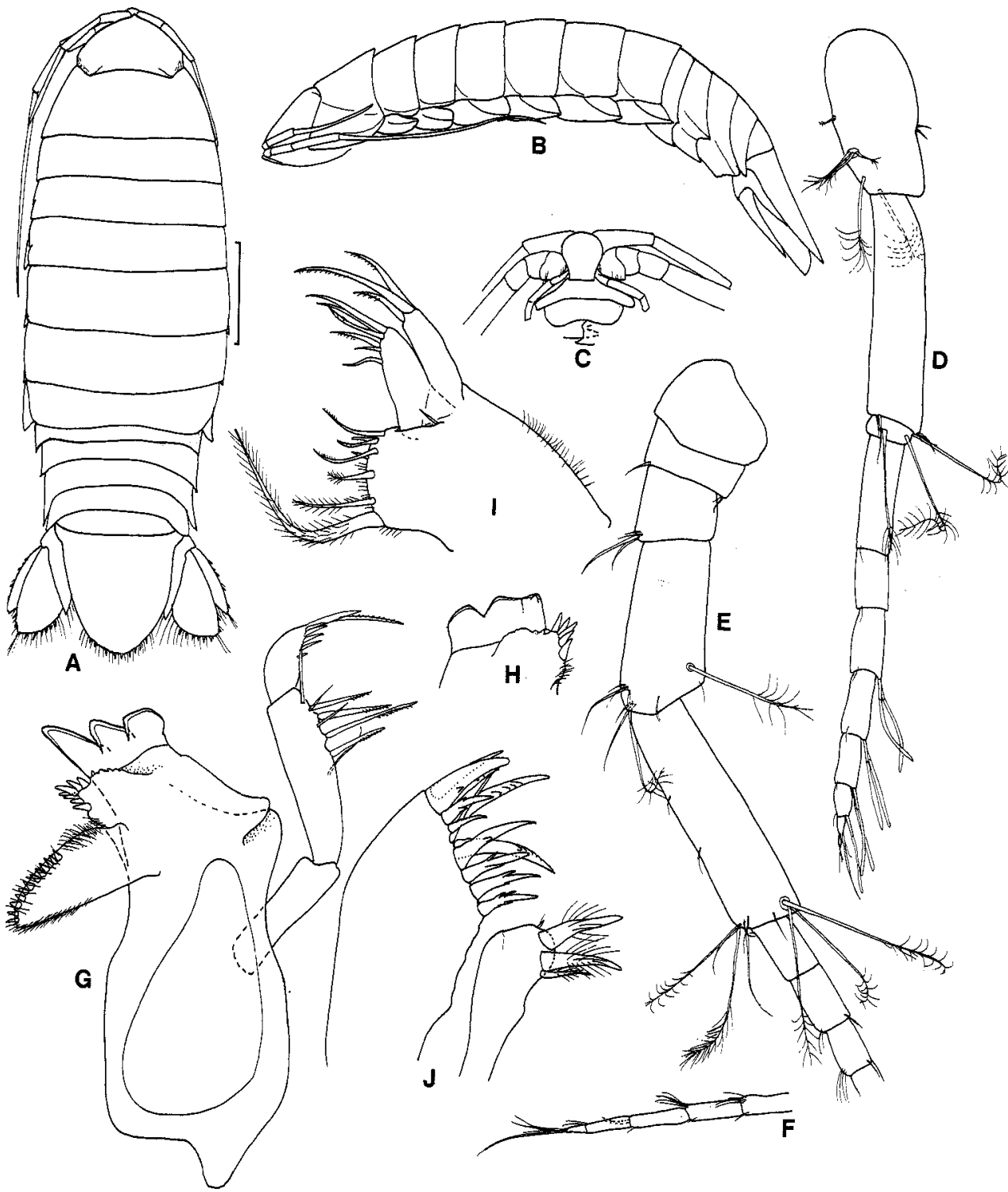

Fig. 1. Haptolana pholeta, sp. nov, $A-C$, holotype; remainder $\sigma$ paratype, $4 \cdot 8 \mathrm{~mm}$. $A$, dorsal view; $B$, lateral view; $C$, frons; $D$, antennule; $E$, antenna peduncle; $F$, antenna, distal articles of flagellum; $G$, right mandible; $H$, left mandible, incisor and spine row; $I$, maxilla; $J$, maxillule. Scale line, $1.0 \mathrm{~mm}$. 


\section{Description}

\section{Male}

Body $3 \times$ as long as greatest width, widest at pereonites 5 and 6 ; pereonite 1 longest, $2<3=4<5=6>7$; coxae 2-7 each with entire diagonal suture; pereonite 1 with 2 fine lateral longitudinal sutures; cephalon with rostral point, without sutures or carinae. Pleotelson linguiform, $0.9 \times$ as long as proximal width; posterior margin with small caudomedial point, on either side of which lie 9 spines set amongst PMS.

Antennule peduncle article $31 \cdot 3 \times$ as long as coalesced articles 1 and 2; article $40 \cdot 1 \times$ as long as article 3; flagellum slightly shorter than peduncle, composed of 7 articles, extending to pereonite 2 . Antenna articles $1-3$ of peduncle short, article $42 \cdot 8 \times$ as long

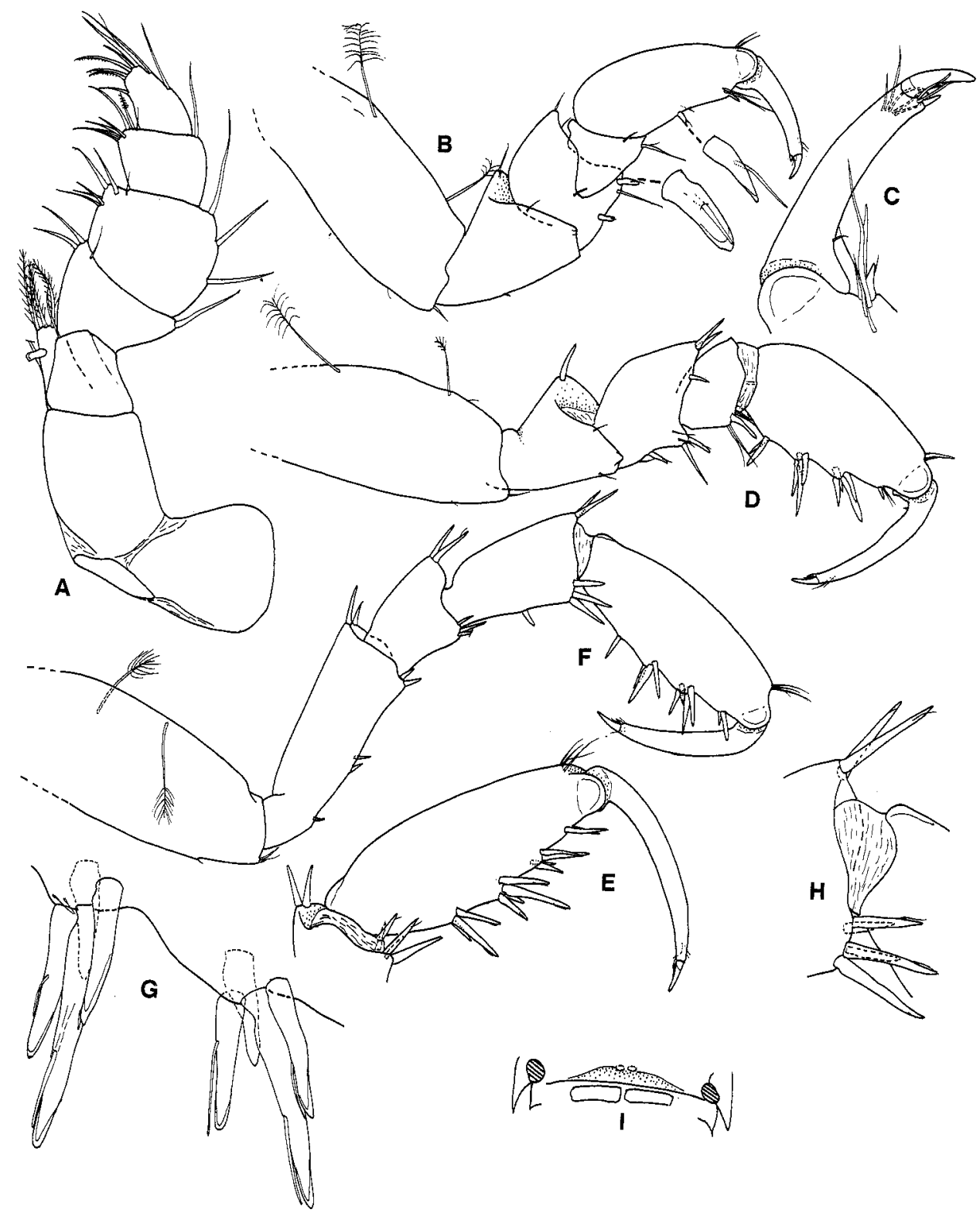

Fig. 2. Haptolana pholeta, sp. nov. All $\sigma$ paratype, $4.8 \mathrm{~mm}$, except $I$ (holotype). $A$, maxilliped; $B$, pereopod $1 ; C$, pereopod 1 , dactylus; $D$, pereopod $2 ; E$, pereopod 6 , propodus; $F$, pereopod 7 ; $G$, spines, pereopod 2, propodus; $H$, distal margin of carpus, pereopod $7 ; 1$, penial papillae. 
as article 3, article $51.3 \times$ as long as article 4 ; distal margin of article 4 with 2 long brushtipped setae, distal margin of article 5 with 5 long brush-tipped setae; flagellum composed of 16 articles, extending to middle of pereonite 5 .

Frontal lamina broadly rounded anteriorly and distolaterally, maximum width $1.7 \times$ as wide as basal width; anterior margin separating antennule bases, visible in dorsal view.

Mandible spine row with 5 (left mandible) or 7 (right) spines, and 2 blunt lateral tubercles; molar process with setules along mesial and proximal lateral margin; lateral margin with 12 teeth, proximal $\frac{1}{3}$ without teeth; article 2 of palp with 4 serrate and 4 simple setae, article 3 with 7 setae, distal 2 of which are manifestly longest. Maxillule lateral lobe with 12 stout spines and 1 slender spine on gnathal surface; mesial lobe with 3 weakly circumplumose spines, proximal one being reduced in size, less than half as wide and $0.66 \times$ as long as others. Maxilla lateral lobe with large recurved circumplumose seta at proximal angle, and further 4 plumose seta and 2 simple setae on mesial margin; middle and lateral lobes with 6 and 3 serrate setae respectively. Maxilliped palp articles 2-5 with

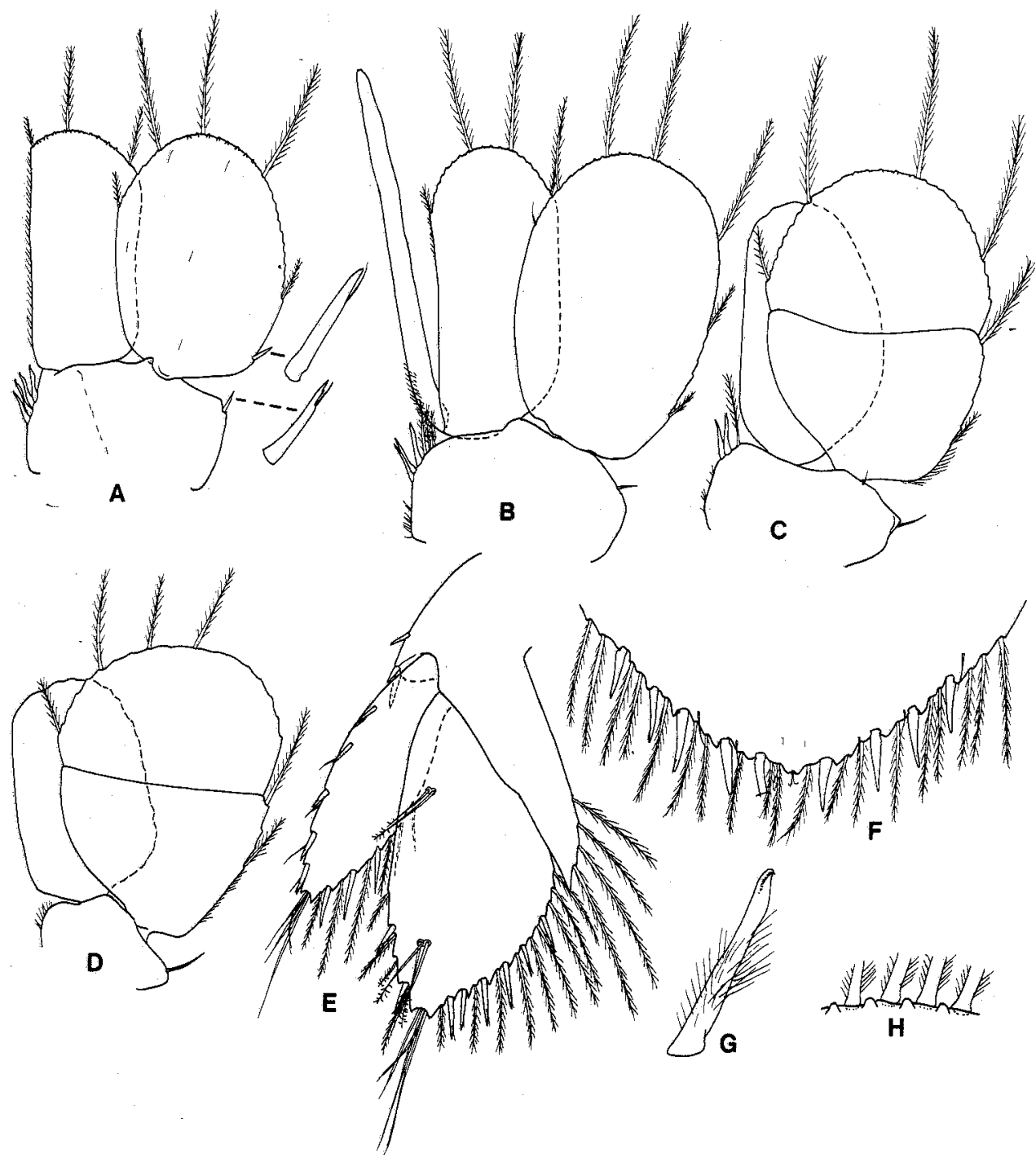

Fig. 3. Haptolana pholeta, sp. nov. All o paratype, $4.8 \mathrm{~mm}$, except $B$ (holotype). $A-D$, pleopods $1-3,5$ respectively; $E$, uropod; $F$, pleotelson, posterior margin; $G$, coupling hook, pleopod $1 ; H$, distal margin of endopod, pleopod 1. 
1, 3, 1 and 2 simple setae respectively on lateral margin; mesial margins with 2, 4, 6 and 7 setae respectively at distomesial angle; endite with 5 circumplumose setae.

Pereopod 1 merus posterior margin with 2 spines and single seta; propodus with single acute spine on palm, second spine opposite base of dactylus; dactylus $0.7 \times$ length of propodus. Pereopod 2 ischium with single spine at anterodistal angle; merus with 2 spines at anterodistal angle, 1 spine on posterior margin, 1 at posterodistal angle and 1 at lateral margin; carpus short, $0.3 \times$ length of propodus, posterodistal angle with 2 spines; propodus with 3 clusters of 2, 4 and 4 spines on palm, 1 spine opposite base of dactylus; dactylus about $0.8 \times$ length of propodus. Pereopod 6 similar to 7 , palm of propodus with 4 clusters of $3,4,4$ and 2 spines; dactylus $0.8 \times$ length of propodus. Pereopod 7 ischium with 2 spines on posterior margin, 2 spines each at posterodistal and anterodistal angles; merus with 2 spines at anterodistal angle, 3 at posterodistal angle; carpus $0.6 \times$ length of propodus, with 1 spine on posterior margin, 2 at anterodistal angle and 5 at posterodistal angle; propodus with clusters of $1,4,4$ and 2 spines on palm; dactylus $0.7 \times$ length of propodus.

Pleopod 1 peduncle $0.65 \times$ as long as wide, with 4 coupling hooks on mesial margin, single short acute spine on lateral margin; distal margin of exopod rounded, with about 30 PMS; single acute spine at proximolateral angle; endopod with 12 setae on distal margin only, mesial margin straight, lateral margin weakly concave; distal margin of both rami with small cuticular nodules between setae. Pleopod 2 generally similar to 1, exopod with about 40 PMS, endopod with 20 PMS; appendix masculina $1 \cdot 3 \times$ as long as endopod. Exopods of pleopods 3-5 each with complete transverse suture, with 34, 32 and 22 PMS respectively; pleopod 5 endopod without distinct proximomesial lobe.

Uropod rami not extending beyond posterior margin of pleotelson. Exopod about $0 \cdot 86 \times$ as long as endopod, apex bifid, mesial process slightly longer than lateral; lateral margin with 5 acute spines each with adjacent simple setae, mesial margin with 3 acute spines and 6 PMS. Lateral margin of endopod with 2 acute spines, 3 simple setae and single sensory seta set between the two spines; mesial margin with 6 acute spines and 9 PMS, apex subequally bifid; peduncle with single short acute spine on lateral margin, 2 spines at ventrolateral angle; distomesial margin with 3 PMS.

\section{Female}

Similar to male; ovigerous females not present.

Size

Males 4.5-6.5 mm, females $4 \cdot 6-6 \cdot 6 \mathrm{~mm}$.

\section{Variation}

The appendix masculina of the largest male (the holotype) is significantly longer than that of the $4.8-\mathrm{mm}$ male dissected, being 1.30 times as long as the endopod in the larger specimen compared with 1.08 in the smaller; the larger male also has more PMS on the rami of pleopod 2 (exopod 40, endopod 20) than the smaller male (exopod 30, endopod 13).

Spine counts for the pleotelson were $8(43 \%, n=7), 9(28 \cdot 5 \%)$ and $10(28 \cdot 5 \%)$. The lateral margin of the uropod exopod had $5(35 \%, n=14)$ or 6 spines $(64 \%)$, the mesial margin most commonly had 3 spines $(93 \%, n=14)$; the lateral margin of the endopod had $2(42 \%, n=14)$ or 3 spines $(50 \%)$, the mesial margin most commonly had $5(57 \%, n=14)$ or 6 spines $(28 \%)$, one specimen each being observed with one ramus with 4 spines and one with 7 spines.

\section{Remarks}

The flat and widely rounded frontal lamina, visible in dorsal view, the straight appendix masculina and the linguiform pleotelson with 8-10 spines immediately separate Haptolana pholeta from its congeners.

\section{Etymology}

The epithet is derived from the Greek pholeter-one who lives in a hole. 


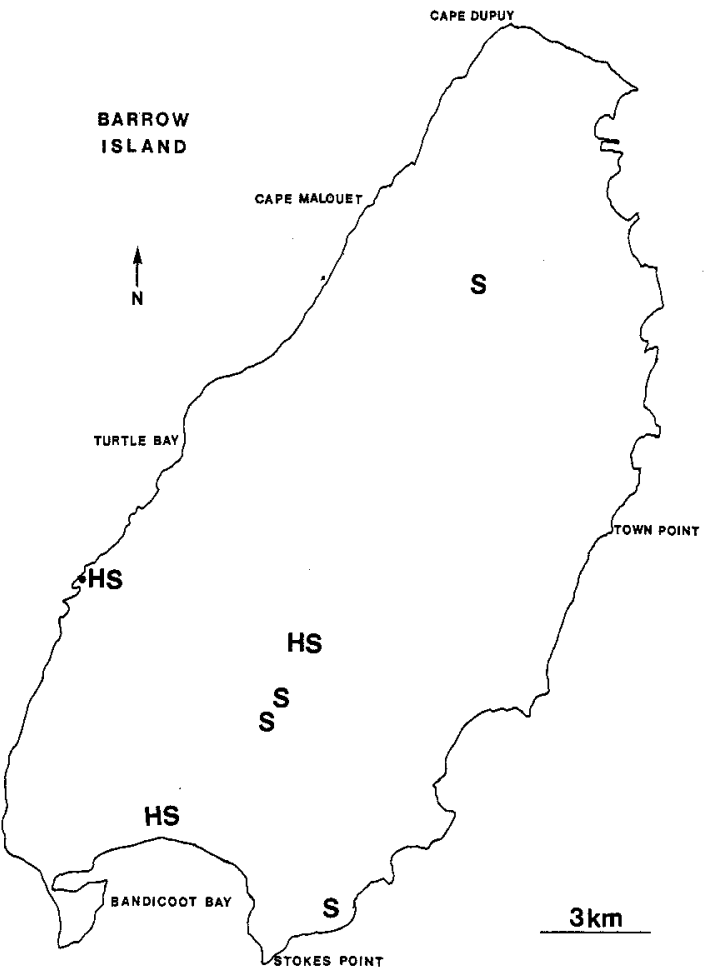

A

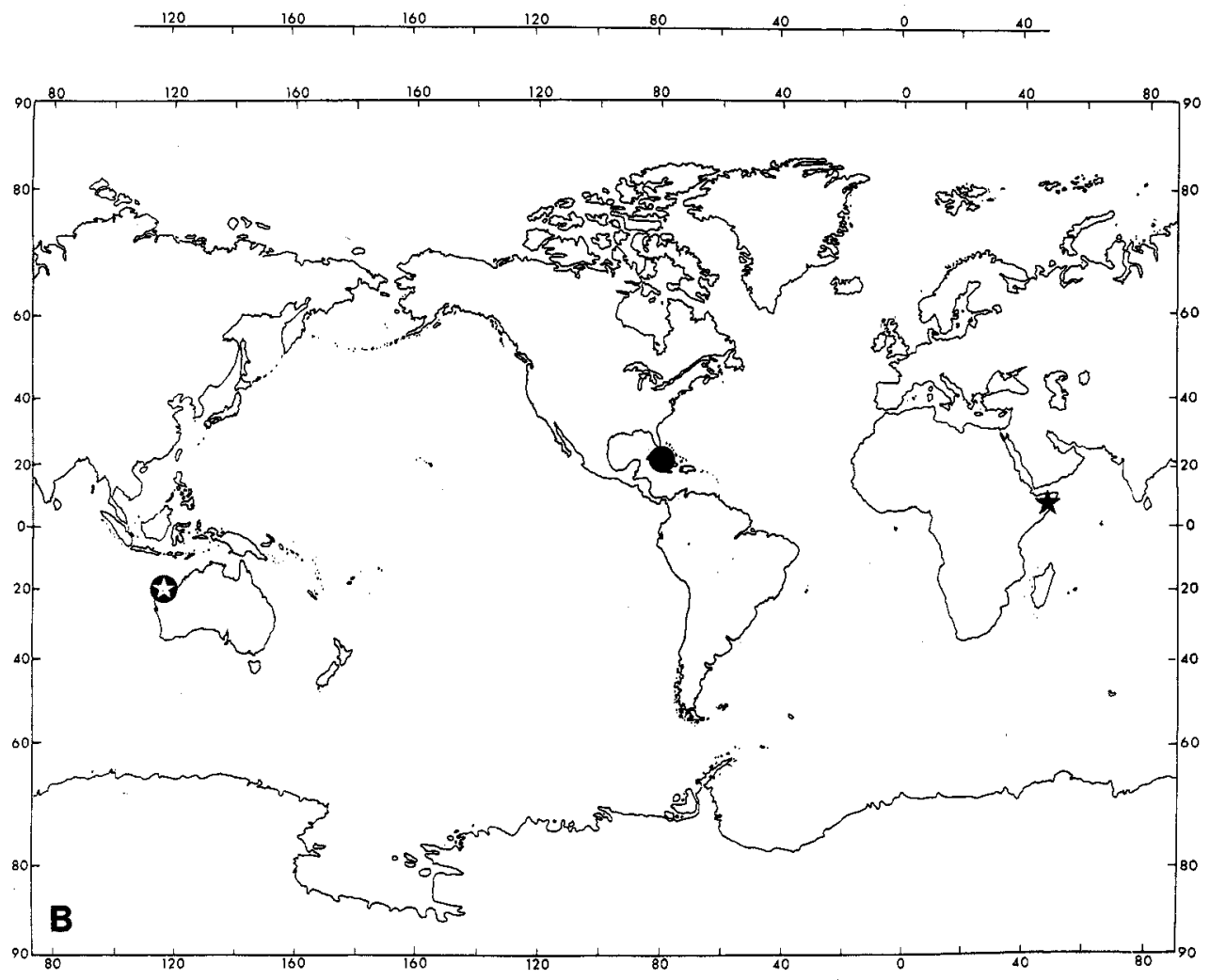

Fig. 4. A, distribution of Haptolana pholeta, sp. nov, (H) and Stygiocaris stylifera (S) on Barrow I. $B$, world distribution of Haptolana: $\$$, Haptolana pholeta; , Haptolana trichostoma; $\star$, Haptolana somala. 
Habitat of Haptolana pholeta

The north-west of Western Australia is currently arid to semiarid and experiences highly unpredictable rainfall (Humphreys et al. 1989). A rich stygofauna inhabits the lowlying areas of the North West Cape peninsula (Humphreys and Adams 1991; Poore and Humphreys 1992) and Barrow Island, $160 \mathrm{~km}$ to the north-east. Both are part of the same geological structure, the Cape Range Formation, which is an anticline capped with Lower Miocene marine limestones, some of which are highly cavernous (Humphreys et al. 1989).

Haptolana pholeta was, together with Stygiocaris stylifera Holthuis (Decapoda: Atyidae), collected at three locations on Barrow Island (Fig. 4): in surface waters of an anchialine cave (Cave B1) opening $40 \mathrm{~m}$ from the sea cliffs, in an old water bore $0.7 \mathrm{~km}$ from the sea shore (Well B2), and in a newly drilled anode bore (Well L16) in the centre of the island, $5 \cdot 15 \mathrm{~km}$ from the nearest sea shore.

Cave B1 is markedly tidal and this is reflected in both the $\mathrm{pH}$ and salinity values (Table 1). The location furthest from the sea (Well L16) is the least saline, as would be expected from hydrodynamic considerations. The acidity of the two wells (Table 1) is probably due to the natural emissions of hydrogen sulphide gas found in parts of Barrow Island.

Table 1. Location and characteristics of collection sites for Haptolana pholeta sp. nov. on Barrow Island

\begin{tabular}{|c|c|c|c|c|c|c|}
\hline $\begin{array}{l}\text { Field } \\
\text { No. }\end{array}$ & Location & Coordinates & Type & $\mathrm{pH}$ & $\begin{array}{l}\text { Salinity } \\
\text { (p.p.t.) }\end{array}$ & $\begin{array}{l}\text { Means of } \\
\text { capture }\end{array}$ \\
\hline 505 & Cave B1 & $20^{\circ} 48^{\prime} \mathrm{S} ., 115^{\circ} 19^{\prime} \mathrm{E}$. & $\begin{array}{l}\text { Anchialine cave, } \\
16 \mathrm{~m} \text { deep } \\
\text { to water }\end{array}$ & $7 \cdot 5$ & 24 & Hand net \\
\hline 520 & Well B2 & $20^{\circ} 52^{\prime} \mathrm{S} ., 115^{\circ} 21^{\prime} \mathrm{E}$ & $\begin{array}{l}\text { Old water bore } \\
\text { c. } 8 \mathrm{~m} \text { deep } \\
\text { to water }\end{array}$ & $6 \cdot 6$ & 25 & Trap \\
\hline 540 & Well L16 & $20^{\circ} 49^{\prime} \mathrm{S} ., 115^{\circ} 23^{\prime} \mathrm{E}$. & $\begin{array}{l}\text { New anode bore } \\
\text { c. } 45 \mathrm{~m} \text { deep } \\
\text { to water }\end{array}$ & $6 \cdot 6$ & 5 & $\begin{array}{l}\text { In water sample, } \\
\text { dead on } \\
\text { capture }\end{array}$ \\
\hline
\end{tabular}

${ }^{\text {A }}$ Strong smell of $\mathrm{H}_{2} \mathrm{~S}$ in water sample, probably due to disturbance of sediment and hence the dead specimen.

\section{Acknowledgments}

We thank Brian Vine, Honorary Associate of the Western Australian Museum, for his essential support in the field, and Dr L. B. Holthuis and M. Adams for examining the shrimp specimens. Field work on Barrow Island was conducted with the permission of the Department of Conservation and Land Management and was funded fully by West Australian Petroleum Pty Ltd. This study was completed while in receipt of an Australian Biological Resources Study grant to N.L.B.

\section{References}

Bănărescu, P. (1990). 'Zoogeography of Freshwaters. Volume 1. General Distribution and Dispersal of Freshwater Animals.' (Aula-Verlag: Weisbaden.) 511 pp.

Botosaneanu, L. (Ed.) (1986). 'Stygolgia Mundi. A Faunistic, Distributional and Ecological Synthesis of the World Fauna Inhabiting Subterranean Waters.' (E. J. Brill: Leiden.) 740 pp.

Botosaneanu, L., and Stock, J. H. (1979). Arubolana imula n. gen., n. sp., the first hypogean cirolanid isopod crustacean found in the Lesser Antilles. Bijdragen tot de Dierkunde 49, 227-33.

Botosaneanu, L., Bruce, N. L., and Nontenboom, J. (1986). Cirolanidae. In 'Stygiofauna Mundi'. (Ed. L. Botosaneanu.) pp. 412-22. (E. J. Brill: Leiden.)

Bowman, T. E. (1966). Haptolana trichostoma, a new genus and species of troglobitic cirolanid isopod from Cuba. International Journal of Speleology 2, 105-7, pls 24-27. 
Bowman, T. E. (1966). Haptolana trichostoma, a new genus and species of troglobitic cirolanid isopod from Cuba. International Journal of Speleology 2, 105-7, pls 24-27.

Bowman, T. E. (1982). Speocirolana pubens and $S$. endeca, new troglobitic isopod crustaceans from Mexico (Flabellifera: Cirolanidae). Association of Mexican Cave Studies Bulletin 8, 13-23, and Texas Memorial Museum Bulletin 28, 13-23.

Bowman, T. E. (1987). Bahalana mayana, a new troglobitic cirolanid isopod from Cozumel Island and the Yucatan Peninsula, Mexico. Proceedings of the Biological Saciety of Washington 100, 659-63.

Bowman, T. E., and Franz, R. (1982). Anopsilana crenata, a new troglobitic cirolanid isopod from Grand Cayman Island, Caribbean Sea. Proceedings of the Biological Society of Washington 95 , 522-9.

Bowman, T. E., and Iliffe, T. M. (1987). Anopsilana lingua, a new freshwater troglobitic isopod from the Palau Islands (Flabellifera:Cirolanidae). Proceedings of the Biological Society of Washington 100, 347-52.

Bruce, A. J. (1992). Pycnisia raptor, a new genus and species of predatory troglobic shrimp (Crustacea : Decapoda: Atydiae) from northern Australia. Invertebrate Taxonomy 6, 553-66.

Bruce, N. L. (1981). Cirolanidae (Crustacea: Isopoda) of Australia: diagnoses of Cirolana Leach, Metacirolana Nierstrasz, Neocirolana Hale, Anopsilana Paulian \& Debouteville and three new genera-Natatolana, Politolana and Cartetolana. Australian Journal of Marine and Freshwater Research 32, 945-66.

Bruce, N. L. (1986). Cirolanidae (Crustacea: Isopoda) of Australia. Records of the Australian Museum, Supplement 6, 1-239.

Bruce, N. L., and Iliffe, T. M. (1993). Anopsilana conditoria, a new species of anchialine troglobitic cirolanid isopod (Crustacea) from the Philippines. Stygologia 8, 225-30.

Carpenter, J. H. (1981). Bahalana geracei n. gen., n. sp., a troglobitic marine cirolanid isopod from Lighthouse Cave, San Salvador Island, Bahamas. Bijdragen tot de Dierkunde 51, 259-67.

Harrison, K., and Poore, G. C. B. (1984). Serolis (Crustacea, Isopoda, Serolidae) from Australia, with a new species from Victoria. Memoirs of the Museum of Victoria 45, 13-31.

Holthuis, L. B. (1986). A new genus and species of subterranean shrimp from Western Australia (Crustacea: Decapoda: Atyidae). Zoologische Mededelingen, Leiden 60, 103-11.

Humphreys, W. F., and Adams, M. (1991). The subterranean aquatic fauna of the North West Cape peninsula, Western Australia. Records of the Western Australian Museum 15, 383-411.

Humphreys, W. F., Adams, M., and Vine, B. (1989). The biology of Schizomus vinei (Chelicerata: Schizomida) in the caves of Cape Range, Western Australia. Journal of Zoology, London 217, 177-201.

Kensley, B., and Schotte, M. (1989). 'Guide to the Marine Isopod Crustaceans of the Caribbean.' (Smithsonian Institution: Washington, D.C.) $308 \mathrm{pp}$.

Messana, G. (1990) [1988]. Stygiobitic isopods of East Africa. Biogeographia 14, 113-24.

Messana, G., and Chelazzi, L. (1984). Haptolana somala n. sp., a phreatobic cirolanid isopod (Crustacea) from the Nogal Valley (northern Somalia). Monitore Zoologico Italiano, n.s. supplemento 19, 291-8.

Newman, W. A. (1991). Origins of Southern Hemisphere endemism, especially among marine crustacea. Memoirs of the Queensland Museum 31, 51-76.

Notenboom, J. (1981). Some new hypogean cirolanid isopod crustaceans from Haiti and Mayaguana (Bahamas). Bijdragen tot de Dierkunde 51, 313-31.

Notenboom, J. (1984). Arubolana parvioculata n. sp. (Isopoda, Cirolanidae) from the interstitial of an intermittent river in Jamaica, with notes on $A$. imula Botosaneanu \& Stock and $A$. aruboides (Bowman \& Iliffe). Bijdragen tot de Dierkunde 54, 51-65.

Paulian, R., and Delamere Deboutteville, C. (1956). Un cirolanide cavernicole a Madagascar [Isopode]. Memoires de l'Institute Scientifique de Madagascar, série A 11, 85-8.

Poore, G. C. B., and Humphreys, W. F. (1992). First record of Thermosbaenacea (Crustacea) from the Southern Hemisphere: a new species from a cave in tropical Western Australia. Invertebrate Taxonomy 6, 719-25.

Poore, G. C. B., and Lew Ton, H. M. (1988). A generic review of the Hyssuridae (Crustacea: Isopoda) with a new genus and new species from Australia. Memoirs of the Museum of Victoria 49, 169-93.

Stebbing, T. R. R. (1900). On Crustacea brought by Dr Willey from the South Seas. In 'Zoological results based on material from New Britain, New Guinea, Loyalty Islands and elsewhere, collected during the years of 1895, 1896 and 1897'. (Ed. A. Willey.) 5(3), 605-9. (Cambridge University Press: Cambridge.)

Wilson, G. D. F., and Ponder, W. F. (1992). Extraordinary new subterranean isopods (Peracarida, Crustacea) from the Kimberley region, Western Australia. Records of the Australian Museum 44, 279-98. 